\title{
When misconceptions impede best practices: evidence supports biological control of invasive Phragmites
}

\author{
Bernd Blossey $(\mathbb{D} \cdot$ Stacy B. Endriss $(\mathbb{D} \cdot$ Richard Casagrande $\cdot$ Patrick Häfliger • \\ Hariet Hinz $(\mathbb{D} \cdot$ Andrea Dávalos $(\mathbb{D} \cdot$ Carrie Brown-Lima • Lisa Tewksbury • \\ Robert S. Bourchier
}

Received: 9 July 2019/Accepted: 26 November 2019/Published online: 5 December 2019

(C) The Author(s) 2019

\begin{abstract}
Development of a biological control program for invasive Phagmites australis australis in North America required 20 years of careful research, and consideration of management alternatives. A recent paper by Kiviat et al. (Biol Invasions 21:2529-2541, 2019. https://doi.org/10.1007/s10530019-02014-9) articulates opposition to this biocontrol program and questions the ethics and thoroughness of the researchers. Here we address inaccuracies and misleading statements presented in Kiviat et al. (2019), followed by a brief overview of why biological control targeting Phragmites in North America can be implemented safely with little risk to native species. Similar to our colleagues, we are very concerned about
\end{abstract}

B. Blossey $(\bowtie) \cdot$ S. B. Endriss · C. Brown-Lima Department of Natural Resources, Cornell University, Ithaca, NY 14853, USA

e-mail: bb22@cornell.edu

R. Casagrande $\cdot$ L. Tewksbury

Department of Plant Sciences and Entomology, University of Rhode Island, Kingston, RI 02881, USA

P. Häfliger · H. Hinz

CABI, 2800 Delémont, Switzerland

\section{A. Dávalos}

Biological Sciences Department, SUNY Cortland, Cortland, NY 13045, USA

\section{R. S. Bourchier}

Agriculture and AgriFood Canada, Lethbridge Research Centre, Lethbridge, AB T1J 4B1, Canada the risks invasive Phragmites represent to North American habitats. But to protect those habitats and the species, including $P$. australis americanus, we come to a different decision regarding biological control. Current management techniques have not been able to reverse the invasiveness of $P$. australis australis, threats to native rare and endangered species continue, and large-scale herbicide campaigns are not only costly, but also represent threats to non-target species. We see implementation of biocontrol as the best hope for managing one of the most problematic invasive plants in North America. After extensive review, our petition to release two host specific stem miners was approved by The Technical Advisory Group for the Release of Biological Control Agents in the US and Canadian federal authorities.

Keywords Biological control · Host specificity · Invasive plant species management $\cdot$ Phragmites

\section{Introduction}

The development of a biological control program for invasive Phagmites australis australis in North America is the culmination of more than 20 years of careful research, and consideration of management alternatives. This work was initiated through a collaboration of wetland managers and scientists, based on widespread concerns of negative impacts of the plant on 
native North American biota and decades of failed attempts, using mostly herbicides, by land managers to reduce $P$. australis australis populations and to prevent its spread (Hazelton et al. 2014; Marks et al. 1994; Martin and Blossey 2013). A recently published paper, however, articulates opposition to this biocontrol program and questions the ethics and thoroughness of the researchers (Kiviat et al. 2019). Broadly, Kiviat et al. (2019) appear concerned that biological control of non-native $P$. australis australis is not well thought-out and release of herbivores would be detrimental to non-target species, including the cooccurring native subspecies Phragmites australis americanus. We believe that the objections raised by Kiviat et al. (2019) are built upon several faulty assumptions and misunderstandings that we feel obliged to address.

To be clear, we agree with Kiviat et al. (2019) that we all have a strong responsibility to protect native species such as $P$. australis americanus from demographic harm. In fact, this shared sense of responsibility is what first compelled an international group of scientists to begin developing biological control for non-native $P$. australis australis in 1998. Many native species, including $P$. australis americanus, have rapidly declined in response to invasion by non-native $P$. australis australis. Further, site-specific chemical or physical control methods are not only economically draining and likely to have long-lasting non-target effects, but are also often unsuccessful at reducing the size or extent of non-native $P$. australis australis invasions. It is therefore because of - not in spite ofour responsibility to protect native species and habitats that we believe that biocontrol, while not entirely riskfree, is a superior alternative to the widespread, expensive and unsuccessful status quo of management through herbicide applications (Hazelton et al. 2014; Martin and Blossey 2013; Quirion et al. 2018).

We have already addressed (Blossey and Casagrande 2016a, b; Casagrande et al. 2018) many of the specific critiques raised by Kiviat et al. (2019) and by previous publications by many of the same authors (Bhattarai et al. 2016; Cronin et al. 2015, 2016). In the following two sections, we specifically address fundamental inaccuracies and misleading statements as presented by Kiviat et al. (2019), followed by a brief overview of Phragmites in North America as a wicked management problem that, in our view, requires safe implementation of biological control as the last best hope to protect or restore thriving native wetlands that include $P$. australis americanus.

\section{Fundamental inaccuracies and misleading statements in Kiviat et al. (2019)}

1. We do not advocate targeting cryptic invaders Kiviat et al. (2019) claim that we advocate targeting cryptic invaders when they cite Casagrande et al. (2018). But this paper focused mainly on grasses as targets of weed biocontrol efforts, not on targeting cryptic invaders. We did cite examples of herbivores with sub-species level specificity (including some herbivores attacking agricultural grasses) and showcased Phragmites as one example. However, the purpose of these examples was to demonstrate that decisions to start biocontrol programs or to release herbivores should be based on species-by-species host specificity evaluations rather than on taxonomic designations.

2. Hybridization events between native $P$. australis americanus and introduced $P$. australis australis appear rare.

Kiviat et al. (2019) claim that the "non-native lineage broadly overlaps and interbreeds with other native and non-native lineages". At a minimum this statement is misleading. Phragmites populations have been sampled intensively from across North America for 20 years (Lambert et al. 2016; Saltonstall 2003; Saltonstall et al. 2016), yet hybridization events between native $P$. australis americanus and introduced $P$. australis australis are documented in only two locations: one in New York and one in Nevada (Saltonstall et al. 2014, 2016) (the event in Virginia requires confirmation). Given the broad geographic overlap between the subspecies, subspecies boundaries therefore appear less fluid than Kiviat et al. (2019) suggest (see section on sub-species specificity below for additional clarification).

3. Phragmites australis is the only reported field host of the two proposed biological control agents, Archanara geminipuncta and A. neurica Kiviat et al. (2019), however, incorrectly claim that the "proposed biological control agents... are not specialists but are oligophagous on multiple 
Phragmites lineages and other wetland grasses, including some economically important species". The authors are misusing results of our host specificity testing. No-choice to starvation tests are the first tier of testing and used for rapid screening. They are designed to be highly conservative; if there is any sign of feeding or development on a species, then the plant species is kept in the testing process for further study. It is inaccurate to use these interim test results to speculate about ecological host range and environmental impact and to suggest future use of the non-target species in the field. Under similar constrained conditions, many animals will exhibit feeding well outside of their host range. All weed biocontrol projects use this process and most generate at least some false-positive results (i.e. feeding on nonhosts) at the no-choice level but with no subsequent feeding on these hosts after field release. As an example, we noted some limited feeding on wheat and rice in our lab tests, however these plants are not in the ecological range of the Archanara species as they commonly grow in proximity to Phragmites in Europe, but they are never attacked by A. geminipuncta or A. neurica. We particularly object to this phrase in Kiviat et al. (2019) regarding our earlier work: "After acknowledging the lack of host specificity...." We made no such acknowledgement and remain confident in our host-range testing results as expanded upon later in the manuscript.

4. There is no published literature indicating that a target weed has developed complete resistance to a released herbivorous biocontrol agent (van Wilgen et al. 2013)

Kiviat et al. (2019) claim that purple loosestrife (Lythrum salicaria) has evolved resistance to released biocontrol agents (citing Stastny and Sargent 2017). This greenhouse study documents only a slight reduction in leaf damage for plant populations that have been exposed to L. salicaria biocontrol agents compared to naïve populations. The measured reduction is not biologically significant; the continent-wide success of specialized biocontrol agents in reducing the competitive ability and negative impacts of $L$. salicaria continues, despite their suggested potential for evolution. Importantly, a biological control agent's success is determined not by damage inflicted on individual plants, but by a reduction in plant populations that reduces negative ecological impacts and the need for chemical or other control methods.

5. All accidentally introduced European Phragmites herbivores have not expanded their host ranges to include native genotypes (Phragmites australis americanus) and Gulf Coast genotypes (Type I or Phragmites australis berlandieri)

Current distributions of temperate European herbivores do not overlap with the subtropical and tropical distribution of $P$. australis berlandieri. As such, there is no record of any of the accidentally introduced European herbivores specialized on Phragmites attacking $P$. australis berlandieri. Furthermore, while several accidentally introduced herbivores now attack native $P$. australis americanus, many others exclusively attack European $P$. australis australis (Blossey 2003), showing that plant traits and herbivore preferences result in species-specific interactions. Therefore, we can never generalize from host use of one specialized herbivore to the next. Consequently, our host specificity tests were not conducted using surrogate herbivore species, as that would be an ecological blunder and irresponsible. Rather, all tests are conducted species by species and that is the procedure we have followed. Our results are specific to the two Archanara species we tested.

6. The biology of the two proposed biological control agents greatly limits use of and potential impact on populations of native North American $P$. australis americanus

Kiviat et al. (2019) have not correctly characterized the life history of the biocontrol agents. For example, it is critical to note that: (a) Archanara eggs, not larvae, overwinter; (b) that the looseness of leaf sheaths of native $P$. australis americanus in the late summer and fall determines female oviposition choice; and c) that while this trait of loose leaf sheaths that fall off from native plants reduces the ability of eggs laid on native $P$. australis americanus to overwinter successfully, it has no bearing on larval choice of stems in the following spring. Despite concerns raised by Kiviat et al. (2019), this trait of loose sheaths on native $P$. australis americanus is present in all regions of North America. Furthermore, our proposed biological control agents will not put 
the newly discovered Mexican native lineages of $P$. australis americanus at risk-the climate envelope of the two proposed biocontrol herbivores does not include areas of the southern US or Central America. As detailed in previous publications, Archanara spp. eggs cannot survive under southern climates, which also excludes the proposed herbivores from establishing on $P$. australis berlandieri (Blossey et al. 2018b, c; Casagrande et al. 2018).

7. Common sense and classical biocontrol safety practices require that all tests be conducted in the country of origin, or in quarantine, to prevent ecological disasters

In contrast, Kiviat et al. (2019) seem to suggest (point 4 and 5 of what they deem critical research, such as effects of food webs) to collect evidence that can only be evaluated using long-term field research in North America. This suggestion does not recognize regulatory and safety requirements that govern biological control releases and prohibits such releases for research purposes.

\section{Phragmites in North America: safely deploying biocontrol in a wicked management system}

Explaining the scientific foundations of weed biological control is beyond the scope of this response, however we now indicate how Phragmites managers and particularly the biological control program have considered some of the issues raised by Kiviat et al. (2019), including an assessment of potential benefits and risks. It is important to note that Phragmites management falls into a category of "wicked environmental problems" and some questions identified by Kiviat et al. (2019) are impossible to answer a priori, regardless of whether management is chemical, mechanical or biological. We can however be guided by lessons from and work conducted in other biocontrol programs.

Sub-species specificity and taxonomy of Phragmites in North America

Taxonomists currently recognize the genus Phragmites in North America as consisting of three subspecies: (1) native $P$. australis americanus
Saltonstall, P.M. Peterson \& Soreng; (2) non-native $P$. australis australis of European origin; and (3) $P$. australis berlandieri, a lineage (Type I) of questionable origin distributed along the Gulf Coast and into South America (E. Fourn.) C.F. Reed (Colin and Eguiarte 2016; Saltonstall 2002; Saltonstall and Meyerson 2016). The subspecies designation between $P$. australis americanus and $P$. australis australis is critical to clarify because it plays an important role in the arguments Kiviat et al. (2019) articulate against biocontrol. Significant morphological distinction exists between these subspecies and there is a proposal to elevate $P$. australis americanus to species status as Phragmites americanus (Saltonstall, P.M. Peterson, \& Soreng) A. Haines, comb. et stat. nov (Haines 2010). If this proposal becomes widely adopted-which we find likely-the entire discussion of sub-species level specificity advanced by Kiviat et al. (2019) is a nonissue.

Situational or site-specific versus regional control

Kiviat and co-authors call for situational control vs. regional or continental control of $P$. australis australis, presumably based on local threat-benefit assessments. This recommendation is in direct conflict with the literature on best management practices for invasive species (Lodge et al. 2006), will allow continued rapid range expansion, and ignores decades of unsuccessful site-specific management approaches for P. australis australis (Hazelton et al. 2014; Marks et al. 1994; Martin and Blossey 2013). Specifically, eradication is only possible for extremely small (100 $\mathrm{m}^{2}$ or less) populations (Quirion et al. 2018) and continued suppression requires repeated application of herbicides every few years with potential (based on other herbicide-based programs) of wideranging non-target effects (Kettenring and Adams 2011). According to land managers, these herbicide campaigns have yielded no lasting ecological benefits (Martin and Blossey 2013). Phragmites australis australis continues to expand locally and regionally and threatens native species, including $P$. australis americanus.

Real threats

Kiviat et al. (2019) are right that we need to weigh relative risks to native species when managing 
Phragmites, but this is incomplete without clearly articulating that threats are already imposed by $P$. australis australis, and that current management practices, despite enormous expenditure, have proven unable to reduce these threats. For example, in the Platte River in Nebraska, introduced P. australis australis negatively affects whooping cranes (Grus americana), the northern Great Plains population of the piping plover (Charadrius melodus), and the interior least tern (Sterna antillarum athalassos) (National Research Council 2004). The Platte River is also important habitat for the endangered pallid sturgeon (Scaphirhynchus albus) and the most important spring staging area for nearly 500,000 sandhill cranes (Grus canadensis) (Kessler et al. 2011), which are both negatively affected by $P$. australis australis (National Research Council 2004). Further, encroachment of $P$. australis australis into the lower portions of the high marsh along the Atlantic Coast reduces the amount of available habitat for bird species adapted to nesting in short marsh grasses (Spartina patens and Distichlis spicata), including the threatened saltmarsh sparrow (Ammodramus caudacutus) (Benoit and Askins 1999). Additional federally listed endangered species negatively affected by introduced $P$. australis australis include (but are not limited to): sensitive joint vetch (Aeschynomene virginica), black rail (Laterallus jamaicensis), bog turtle (Glyptemys muhlenbergii), lakeside daisy (Tetraneuris herbacea), dwarf lake iris (Iris lacustris), Mitchell's satyr (Neonympha mitchellii) and the northeastern beach tiger beetle (Cicindela dorsalis) (US Fish and Wildlife Service 1990, 1994, 1995, 1997, 2001, 2013, 2018).

In Canada, invasive $P$. australis australis has spread throughout the Carolinian forest region and is common across southern Ontario and the St. Lawrence River watershed in Quebec (Kettenring et al. 2012). Examples of federally listed species in Canada that are directly threatened by introduced $P$. australis australis include: the prothonotary warbler (Protonotaria citrea), Fowler's toad (Anaxyrus fowleri), piping plover (Charadrius melodus), Blanding's turtle (Emydoidea blandingii), spotted turtle (Clemmys guttata) and bent spike-rush (Eleocharis geniculata) (COSEWIC 2007, 2009, 2010, 2013, Markle et al. 2018; Markle and Chow-Fraser 2018). Furthermore, not a single herbicide that is effective against emergent aquatic plants such as $P$. australis australis is currently approved for use in Canada.
All native species, regardless of whether they are listed or not, deserve our protection, and current management of non-native Phragmites using herbicides, physical, and mechanical control is not the answer. Biological control seems to hold the only hope for ameliorating these problems.

\section{Consideration of plant harm}

Kiviat and colleagues consider harm to non-target plants to be attack on individuals that results in some level of performance reduction. This however, contradicts the generally acknowledged standard for the review of biological control agents and the Endangered Species Act which interpret harm and risk at the population level (i.e. interpreted using demography and population dynamics) (Blossey et al. 2018a; Campbell et al. 2002; Davis et al. 2006). Under this standard, attack - and potentially even death-of individual non-target plants is acceptable as long as the populations of those individuals do not decline, which makes strong ecological and evolutionary sense. All native, and many introduced, plants are attacked by many different herbivores without jeopardizing the existence of host plant populations. For example, larvae of the monarch butterfly (Danaus plexippus) frequently defoliate stems of their milkweed hosts (Asclepias spp.) but the monarch is no threat to Asclepias populations. And while Lipara spp. attack $P$. australis americanus in North America and reduce seed output, we have documented that native Phragmites populations in New York that are not encroached upon by $P$. australis australis have expanded even under considerable Lipara attack rates (Blossey and Nuzzo, unpublished data). Because of this anticipated lack of impact on populations, we never considered Lipara spp. as potential biocontrol agents. Similar examples are plentiful in the plantinsect literature - a bite or even defoliation does not necessarily result in negative demographic consequences, and sometimes does not even reduce the performance of individual plants (Crawley 1989). Even within biocontrol there are many examples of well-established specialized agents that do not exert sufficient demographic pressure to reduce the size of their host plant populations (Myers and Sarfraz 2017). Our host range tests and observations in Europe indicate that there will be no reproduction and little, if any, feeding on non-target species outside of the genus 
Phragmites. Where feeding may occur, we consider that the potential impact to individual stems will not be of sufficient severity that it constitutes a demographic threat to populations.

Host specificity testing and evolution of host specificity in herbivorous biocontrol agents

Critiques of host-specificity testing often fail to acknowledge the science and evidence-based approach to host-range testing developed by biocontrol scientists over decades (Briese 2005; Cullen 1990; Marohasy 1998; Sheppard et al. 2005; USDA 2000, 2016). Host specificity testing is structured to err on the side of caution and to identify an herbivore's fundamental (or physiological) host range (i.e., identify any possibility that the herbivore could attack or develop on a host plant, starting with no-choice tests, through multiple-choice tests and, when possible, open field comparisons in the country of origin). Following introduction and field release, however, these same herbivores express their ecological or realized host range, which is always smaller than their fundamental host range given both ecological and evolutionary constraints. Determining an herbivore's fundamental host range is important, but is only the first step in determining which herbivores merit further investigation as potential biocontrol agents.

Insects make dietary choices based on fundamental needs of nutritional intake, safety from or ability to defend against predators and diseases and other ecological complexities that cannot be replicated in host specificity investigations. But they need to be considered when interpreting data. Predictions of future realized host ranges improve as host specificity tests become more realistic. The most reductionist experiments (no-choice, not allowing dispersal, etc.) create many false positives (Clement and Cristofaro 1995), but the realized host range of a herbivore is the only metric that really matters. This was evident in our tests with the two Archanara spp. where female oviposition choice became most constrained and largely limited to $P$. australis australis as realism of tests increased (Blossey et al. 2018c).

Furthermore, while evolution of host specificity is clearly documented in phylogenetic lineages $(\mathrm{Fu}-$ tuyma 1991; Futuyma and Agrawal 2009), there is no evidence for evolution of host specificity in herbivorous biocontrol agents (Arnett and Louda 2002; van
Klinken and Edwards 2002). In fact, herbivores pay physiological and fitness penalties for making poor dietary choices (Morimoto and Lihoreau 2019; Raubenheimer and Simpson 2018; Wilson et al. 2019), meaning that host specificity is largely maintained by natural selection. While biocontrol scientists and others have documented non-target attack by released biocontrol agents (Hinz et al. 2019), there are only two examples of biocontrol agents (out of nearly 500 species that were released worldwide) that have had (predictable) demographic consequences on nontarget species. A full discussion of the history of host specificity testing and non-target attack is available elsewhere (Blossey et al. 2018a; Suckling and Sforza 2014)

Finally, we once again reject the comparison of the two Archanara species with several other accidentally introduced Phragmites herbivores that are spreading in North America and now attack P. australis americanus. There are other European species that have retained their sub-species level specificity and are never found on $P$. australis americanus and several North American Phragmites herbivores that have not switched to introduced $P$. australis australis (Blossey 2003; Park and Blossey 2008). What determines these differences among herbivores is unclear, but it once again points to species-specific interactions that defy generalization and simple extrapolations. The diet choice of Lipara or other native or accidentally introduced Phragmites herbivores does not predict diet choice by Archanara.

Introduced $P$. australis australis does not provide exclusive benefits

Kiviat et al. (2019) claim that introduced P. australis australis has significant ecological and societal benefits, previously summarized by Kiviat (2013). Importantly, however, use of Phragmites habitat does not imply that the species provides essential habitat or even a preference for Phragmites. Further, references cited by Kiviat (2013) documenting bird use of Phragmites as preferred habitat often refer to native $P$. australis americanus, not invasive $P$. australis australis. For example, $P$. australis australis had not invaded the Grand Canyon as of 2017 (B. Blossey, unpublished data), consequently bird use listed by the original source Spence (2006) and referenced by Kiviat (2013) refers to native $P$. australis americanus. 
Similarly, Phragmites habitat used by Yuma clapper rails (Rallus longirostris yumanensis) in 1985 (Anderson and Ohmart 1985) was native P. australis americanus, since introduced $P$. australis australis did not arrive in the Southwest until decades later.

Other beneficial uses can either be achieved by using native $P$. australis americanus (such as in wastewater treatment plants) or be better accomplished by using more appropriately adapted native plant alternatives. There is not a single use benefit, ecological or otherwise, where we do not have native alternatives that do not come with the inherent negative impacts of using $P$. australis australis. For example, Kiviat and colleagues frequently claim that introduced Phragmites is particularly valuable in (1) stabilizing coastal shorelines during storm events; and (2) increasing sediment accretion that can then ameliorate sea-level rise along the Atlantic Coast and the Gulf of Mexico. For P. australis australis to be effective under either circumstance, however, the species would need to be salt-tolerant and outperform native species, such as Spartina spp. that it replaces. In fact, the opposite is true with Spartina spp. showing higher salt tolerance than $P$. australis australis in North America (Vasquez et al. 2006), which is why tidal flow restoration effectively suppresses $P$. australis australis (Karberg et al. 2015). Further, we have no evidence that coastal marshes invaded by $P$. australis australis suffer less erosion than those dominated by native plant species during the frequent storms and hurricanes along the East Coast or the Gulf of Mexico. The studies referenced in Kiviat et al. (2019) and Knight et al. (2018) to support this first claim lack field evidence, and at best represent experiments conducted in artificial water tanks. Even the studies that investigate sediment accretion rates do not show a clear benefit of introduced Phragmites relative to native alternatives. The only study on sediment accretion rates (Rooth and Cornwell 2003) compares two adjacent $P$. australis australis clones in Maryland (one 20 years old, the other 5 years old) to two nearby areas occupied by native species (Typha spp. and Panicum virgatum), both with very limited salt tolerance. Not only are the reported accretion rates of $P$. australis australis similar to many other species and coastal wetlands (Breithaupt et al. 2018), results from a single clone cannot be generalized to the entire Atlantic Coast or all of coastal North America. As Breithaupt et al. (2018) caution in their review of vertical rise of coastal marshes over time "rates vary significantly as a function of measurement timescale and that the pattern and magnitude of variation between timescales are location-specific. Failure to identify and account for temporal variability in rates will produce biased assessments of the vertical change capacity of coastal wetlands". Examination of the evidence Kiviat and colleagues cite, and of the wider literature, therefore fails to support their claims. At the present time we conclude that the claimed service benefits of coastal $P$. australis australis populations are assumed, not documented.

Raising the bar: evidence requirements in invasive plant management

In the inaugural issue of Biological Invasions we advocated for appropriate data and long-term investigations into impacts of introduced species, as well as impacts of the chosen management technique on native biota to guide management of invasive species (Blossey 1999). Potential unintended consequences are not unique to biological control and the same high standard of evidence should be required to assess all management alternatives, including mechanical, physical, chemical control and doing nothing. Unfortunately, this is still not the standard in invasive species management, and the reasons for absence of this information may include many factors, including lack of both funding and appropriate metrics. There is little apparent effort to assess the outcome of repeated, large-scale herbicide treatments of $P$. australis australis that may be harming species we wish to protect (Kettenring and Adams 2011). Herbicide resistance is common among targeted weeds. Further, glyphosate, the most commonly used herbicide in Phragmites management, is suspected to increase human cancer rates (Pollack 2015). We echo the call for increased collection of long-term evidence when making management decisions, but we deem it inappropriate to single out biological control.

We have addressed several of the "critical" needs enumerated by Kiviat et al. (2019) (non-targets, natural enemies, resistance), but others are impossible to address with any reliability. We have used the best available evidence to gauge future distributions and biological interactions with knowledge of specialized invertebrate predators and parasitoids, bird and bat predation and food web effects using data from North 
America and the native range (Blossey et al. 2018c; Casagrande et al. 2018). Climate models provide the illusion of accuracy, but typically have a poor track record. Plant and animal distributions are not solely determined by climate but also by land-use and biotic interaction and they also evolve (Sexton et al. 2009; Sobek-Swant et al. 2012; Thuiller et al. 2008; Venette 2017). Accurate forecasting of evolution (such as resistance to biocontrol agents), or of food web effects (including potential natural enemies across North America) is difficult, if not impossible, because these effects will differ spatially, temporally and fluctuate with local conditions and abundance of biocontrol herbivores. Kiviat and co-authors remain silent about the scope of these exercises and just what they may consider sufficient evidence to allow decision making. In essence, Kiviat et al. (2019) raise the bar impossibly high — a standard that would preclude all management techniques. That appears to be a risk few are willing to take given the threats posed by introduced species. But we certainly agree that management should be guided by more evidence of impacts and outcomes to retain support and remain accountable to society and our stewardship obligations.

\section{Conclusions}

The continued local and regional expansion of $P$. australis australis has clear detrimental impacts on many native species, including listed endangered species in the US and Canada. There are currently no effective management approaches available to land managers except frequent use of herbicides, which has not been successful, desirable, or affordable. Consequently, land managers and their agencies have initiated and sponsored development of biological control. While Kiviat et al. (2019) may have a fundamental opposition to biological control, they offer no workable management alternative. Our risk evaluation based on realized current threats of $P$. australis australis, our testing results, potential demographic effects and harm to non-target populations concludes that these risks are small compared to the risks of not implementing biocontrol of invasive $P$. australis australis (Blossey and Casagrande 2016a, b, Blossey et al. 2018b, c). After two decades of careful evaluation of host specificity of two stem-boring moths, we proposed introduction of A. geminipuncta and A. neurica to North America to federal regulatory agencies in the US and Canada. Our 153-page release petition to the USDA Technical Advisory Group and regulatory agencies in Canada was reviewed by federal and state agency representatives from the USA, Canada, and Mexico. After careful considerations of all aspects of this program both species were recommended for release. Similar to our colleagues, we are very concerned about the risks invasive Phragmites represent to North American habitats. But to protect those habitats and the species, including $P$. australis americanus, we come to a fundamentally different decision regarding biological control. We see it as the best hope for managing one of the most problematic invasive plants in North America.

Open Access This article is licensed under a Creative Commons Attribution 4.0 International License, which permits use, sharing, adaptation, distribution and reproduction in any medium or format, as long as you give appropriate credit to the original author(s) and the source, provide a link to the Creative Commons licence, and indicate if changes were made. The images or other third party material in this article are included in the article's Creative Commons licence, unless indicated otherwise in a credit line to the material. If material is not included in the article's Creative Commons licence and your intended use is not permitted by statutory regulation or exceeds the permitted use, you will need to obtain permission directly from the copyright holder. To view a copy of this licence, visit http://creativecommons.org/licenses/by/4.0/.

\section{References}

Anderson BW, Ohmart RD (1985) Habitat use by clapper rails in the lower Colorado River valley. Condor 87:116-126

Arnett AE, Louda SM (2002) Re-test of Rhinocyllus conicus host specificity, and the prediction of ecological risk in biological control. Biol Conserv 106:251-257

Benoit LK, Askins RA (1999) Impact of the spread of Phragmites on the distribution of birds in Connecticut tidal marshes. Wetlands 19:194-208

Bhattarai GP, Allen WJ, Cronin JT, Kiviat E, Meyerson LA (2016) Response to Blossey and Casagrande: ecological and evolutionary processes make host specificity at the subspecies level exceedingly unlikely. Biol Invasions 18:2757-2758

Blossey B (1999) Before, during, and after: the need for longterm monitoring in invasive plant species management. Biol Invasions 1:301-311

Blossey B (2003) A framework for evaluating potential ecological effects of implementing biological control of Phragmites australis. Estuaries 26:607-617

Blossey B, Casagrande R (2016a) Biological control of invasive Phragmites may safeguard native Phragmites and increase wetland conservation values. Biol Invasions 18:2753-2755 
Blossey B, Casagrande RA (2016b) Response to Bhattarai et al.: Trait differences between native and introduced genotypes results in subspecies level specificity in select Phragmites herbivores. Biol Invasions 18:2759-2760

Blossey B, Dávalos A, Simmons W, Ding J (2018a) A proposal to use plant demographic data to assess potential weed biological control agents impacts on non-target plant populations. Biocontrol 63:461-473

Blossey B, Häfliger P, Tewksbury L, Dávalos A, Casagrande R (2018b) Complete host specificity test plant list and associated data to assess host specificity of Archanara geminipuncta and Archanara neurica, two potential biocontrol agents for invasive Phragmites australis. Data in Brief 19:1755-1764. https://doi.org/10.1016/j.dib.2018.06.068

Blossey B, Häfliger P, Tewksbury L, Dávalos A, Casagrande R (2018c) Host specificity and risk assessment of Archanara geminipuncta and Archanara neurica, two potential biocontrol agents for invasive Phragmites australis in North America. Biol Control 125:98-112. https://doi.org/10. 1016/j.biocontrol.2018.1005.1019

Breithaupt JL, Smoak JM, Byrne RH, Waters MN, Moyer RP, Sanders CJ (2018) Avoiding timescale bias in assessments of coastal wetland vertical change. Limnol Oceanogr 63:S477-S495

Briese DT (2005) Translating host-specificity test results into the real world: the need to harmonize the yin and yang of current testing procedures. Biol Control 35:208-214

Campbell SP, Clark JA, Crampton LH, Guerry AD, Hatch LT, Hosseini PR, Lawler JJ, O'Connor RJ (2002) An assessment of monitoring efforts in endangered species recovery plans. Ecol Appl 12:674-681

Casagrande RA, Häfliger P, Hinz H, Tewksbury L, Blossey B (2018) Grasses as appropriate targets in weed biocontrol: is the common reed, Phragmites australis, an anomaly? Biocontrol 63:391-403

Clement SL, Cristofaro M (1995) Open field tests in hostspecificity determination of insects for biological control of weeds. Biocontrol Sci Technol 5:395-406

Colin R, Eguiarte LE (2016) Phylogeographic analyses and genetic structure illustrate the complex evolutionary history of Phragmites australis in Mexico. Am J Bot 103:876-887

COSEWIC (2007) COSEWIC assessment and status report on the prothonotary warbler Protonotaria citrea in Canada. Committee on the Status of Endangered Wildlife in Canada, Ottawa

COSEWIC (2009) COSEWIC assessment and status report on the bent spike rush Eleocharis geniculata, Great Lakes Plains population and Southern Mountain population, in Canada. Committee on the Status of Endangered Wildlife in Canada, Ottawa

COSEWIC (2010) COSEWIC assessment and status report on the Fowler's toad Anaxyrus fowleri in Canada. Committee on the Status of Endangered Wildlife in Canada, Ottawa

COSEWIC (2013) COSEWIC assessment and status report on the piping plover circumcinctus subspecies (Charadrius melodus circumcinctus) and the melodus subspecies (Charadrius melodus melodus) in Canada. Committee on the Status of Endangered Wildlife in Canada, Ottawa. (www.registrelep-sararegistry.gc.ca/default_e.cfm). Accessed 16 June 2019
Crawley MJ (1989) Insect herbivores and plant population dynamics. Annu Rev Entomol 34:531-564

Cronin JT, Bhattarai GP, Allen WJ, Meyerson LA (2015) Biogeography of a plant invasion: plant-herbivore interactions. Ecology 96:1115-1127

Cronin JT, Kiviat E, Meyerson LA, Bhattarai GP, Allen WJ (2016) Biological control of invasive Phragmites australis will be detrimental to native $P$. australis. Biol Invasions 18:2749-2752

Cullen JM (1990) Current problems in host-specificity screening In: Delfosse ES (ed) Proceedings of the 7th international symposium on biological control of weeds, Rome, Italy, Istituto Sperimentale per la Patologia Vegetale, MAF Rome, pp 27-36

Davis AS, Landis DA, Nuzzo V, Blossey B, Gerber E, Hinz HL (2006) Demographic models inform selection of biocontrol agents for garlic mustard (Alliaria petiolata). Ecol Appl 16:2399-2410

Futuyma DJ (1991) Evolution of host specificity in herbivorous insects: genetic, ecological, and phylogenetic aspects. In: Price P, Lewinsohn T, Fernandes G, Benson W (eds) Plantanimal interactions: evolutionary ecology in tropical and temperate regions. Wiley, New York, pp 431-454

Futuyma DJ, Agrawal AA (2009) Macroevolution and the biological diversity of plants and herbivores. Proc Nat Acad Sci USA 106:18054-18061

Haines A (2010) Stantec Botanical Notes 13:5. http://www. scribd.com/StantecInc. Accessed 16 June 2019

Hazelton ELG, Mozdzer TJ, Burdick DM, Kettenring KM, Whigham DF (2014) Phragmites australis management in the United States: 40 years of methods and outcomes. AoB Plants 6:plu0011. https://doi.org/10.1093/aobpla/plu001

Hinz HL, Winston RL, Schwarzländer M (2019) How safe is weed biological control? A global review of direct nontarget attack. Q Rev Biol 91:1-27

Karberg JM, Beattie KC, O'Dell DI, Omand KA (2015) Salinity tolerance of common reed (Phragmites australis) at the Medouie Creek restoration site, Nantucket MA. Wetland Sci Pract 32:19-23

Kessler AC, Merchant JW, Allen CR, Shultz SD (2011) Impacts of invasive plants on Sandhill Crane (Grus canadensis) roosting habitat. Invasive Plant Sci Manag 4:369-377

Kettenring KM, Adams CR (2011) Lessons learned from invasive plant control experiments: a systematic review and meta-analysis. J Appl Ecol 48:970-979

Kettenring KM, Blois Sd, Hauber DP (2012) Moving from a regional to a continental perspective of Phragmites australis invasion in North America. AoB Plants. https://doi. org/10.1093/aobpla/pls040

Kiviat E (2013) Ecosystem services of Phragmites in North America with emphasis on habitat functions. AoB Plants. https://doi.org/10.1093/aobpla/plt1008

Kiviat E, Meyerson LE, Mozdzer TJ, Allen WJ, Baldwin AH, Bhattarai GP, Brix H, Caplan JS, Kettenring KM, Lambertini C, Weis J, Whigham DF, Cronin JT (2019) Evidence does not support the targeting of cryptic invaders at the subspecies level using classical biological control: the example of Phragmites. Biol Invasions 21:2529-2541. https://doi.org/10.1007/s10530-019-02014-9

Knight IA, Wilson BE, Gill M, Aviles L, Cronin JT, Nyman JA, Schneider SA, Diaz R (2018) Invasion of Nipponaclerda 
biwakoensis (Hemiptera: Aclerdidae) and Phragmites australis die-back in southern Louisiana, USA. Biol Invasions 20:2739-2744

Lambert AM, Saltonstall K, Long R, Dudley TL (2016) Biogeography of Phragmites australis lineages in the southwestern United States. Biol Invasions 18:2597-2617

Lodge DM, Williams S, MacIsaac HJ, Hayes KR, Leung B, Reichard S, Mack RN, Moyle PB, Smith M, Andow DA, Carlton JT, McMichael A (2006) Biological invasions: recommendations for US policy and management. Ecol Appl 16:2035-2054

Markle CE, Chow-Fraser P (2018) Effects of European common reed on Blanding's turtle spatial ecology. J Wildl Manag 82:857-864

Markle CE, Chow-Fraser G, Chow-Fraser P (2018) Long-term habitat changes in a protected area: implications for herpetofauna habitat management and restoration. PLoS One 13:e0192134

Marks M, Lapin B, Randall JA (1994) Phragmites australis (P. communis): threats, management and monitoring. Nat Areas J 14:285-294

Marohasy J (1998) The design and interpretation of hostspecificity tests for weed biological control with particular reference to insect behavior. Biocontrol 19:13-20

Martin LJ, Blossey B (2013) The runaway weed: costs and failures of Phragmites australis management in the USA. Estuaries Coasts 36:626-632

Morimoto J, Lihoreau M (2019) Quantifying nutritional tradeoffs across multidimensional performance landscapes. Am Nat 193:E168-E181

Myers JH, Sarfraz RM (2017) Impacts of insect herbivores on plant populations. Annu Rev Entomol 62:207-230

National Research Council (2004) Endangered and threatened species of the Platte River. National Academies, Washington, DC

Park MG, Blossey B (2008) Importance of plant traits and herbivory for invasiveness of Phragmites australis (Poaceae). Am J Bot 95:1557-1568

Pollack A (2015) Weed killer, long cleared, is doubted. New York Times, New York

Quirion B, Simek Z, Dávalos A, Blossey B (2018) Management of invasive Phragmites australis in the Adirondacks: a cautionary tale about prospects of eradication. Biol Invasions 20:59-73

Raubenheimer D, Simpson SJ (2018) Nutritional ecology and foraging theory. Curr Opin Insect Sci 27:38-45

Rooth JE, Cornwell JC (2003) Increased sediment accretion rates following invasion by Phragmites australis: the role of litter. Estuaries 26:475-483

Saltonstall K (2002) Cryptic invasion by a non-native genotype of the common reed, Phragmites australis, into North America. Proc Nat Acad Sci USA 99:2445-2449

Saltonstall K (2003) Genetic variation among North American populations of Phragmites australis: implications for management. Estuaries 26:444-451

Saltonstall K, Meyerson LA (2016) Phragmites australis: from genes to ecosystems. Biol Invasions 18:2415-2420

Saltonstall K, Castillo HE, Blossey B (2014) Confirmed field hybridization of native and introduced Phragmites australis (Poaceae) in North America. Am J Bot 101:211-215
Saltonstall K, Lambert AM, Rice N (2016) What happens in Vegas, better stay in Vegas: Phragmites australis hybrids in the Las Vegas Wash. Biol Invasions 18:2463-2474

Sexton JP, McIntyre PJ, Angert AL, Rice KJ (2009) Evolution and ecology of species range limits. Annu Rev Ecol Evol Syst 40:415-436

Sheppard AW, van Klinken RD, Heard TA (2005) Scientific advances in the analysis of direct risks of weed biological control agents to nontarget plants. Biol Control 35:215-226

Sobek-Swant S, Kluza DA, Cuddington K, Lyons DB (2012) Potential distribution of emerald ash borer: What can we learn from ecological niche models using Maxent and GARP? Forest Ecol Manag 281:23-31

Spence JR (2006) The riparian and aquatic bird communities along the Colorado River from Glen Canyon Dam to Lake Mead, 1996-2000. Unpublished report to Grand Canyon Monitoring and Research Center, Flagstaff, Arizona. Glen Canyon National Recreation Area, Page, Arizona. http:// www.riversimulator.org/Resources/GCMRC/Terrestrial/ Spence2006.pdf. Accessed 16 June 2019

Stastny M, Sargent RD (2017) Evidence for rapid evolutionary change in an invasive plant in response to biological control. J Evol Biol 30:1042-1052

Suckling DM, Sforza RFH (2014) What magnitude are observed non-target impacts from weed biocontrol? PLoS One 9(1):e84847. https://doi.org/10.1371/journalpone0084847

Thuiller W, Albert C, Araujo MB, Berry PM, Cabeza M, Guisan A, Hickler T, Midgely GF, Paterson J, Schurr FM, Sykes MT, Zimmermann NE (2008) Predicting global change impacts on plant species' distributions: future challenges. Perspect Plant Ecol Evol Syst 9:137-152

US Fish and Wildlife Service (1990) Recovery plan for the Lakeside Daisy (Hymenoxys acaulis var glabra). Twin Cities, Minnesota

US Fish and Wildlife Service (1994) Northeastern Beach Tiger Beetle (Cicindela dorsalis dorsalis Say) Recovery Plan. Hadley, Massachusetts

US Fish and Wildlife Service (1995) Sensitive Joint-Vetch (Aeschynomene virginica) Recovery Plan. Hadley, Massachusetts

US Fish and Wildlife Service (1997) Recovery Plan for Mitchell's Satyr Butterfly (Neonympha mitchellii mitchelii French). Fort Snelling, Minnesota

US Fish and Wildlife Service (2001) Bog Turtle (Clemmys muhlenbergii) Northern Population Recovery Plan. Hadley, Massachusetts

US Fish and Wildlife Service (2013) Dwarf Lake Iris (Iris lacustris) Recovery Plan. Bloomiongton, Minnesota

US Fish and Wildlife Service (2018) Endangered and threatened wildlife and plants; 12-month petition finding and threatened species status for eastern black rail with a Section 4(d) Rule. Federal Register vol 83, Docket No. FWSR4-ES-2018-0057; 4500030113; https://www.gpo.gov/ fdsys/pkg/FR-2018-10-09/pdf/2018-21799.pdf. Accessed 16 June 2019

USDA (2000) Reviewer's Manual for the Technical Advisory Group for Biological Control Agents of Weeds: Guidelines for Evaluating the Safety of Candidate Biological Control Agents. United States Department of Agriculture, Animal 
Plant Health Inspection Service, Plant Protection and Quarantine, Riverdale, Maryland United States

USDA (2016) Technical Advisory Group For Biological Control Agents Of Weeds Manual, Interim edn. United States Department of Agriculture, Washington

van Klinken RD, Edwards OR (2002) Is host specificity of weed biocontrol agents likely to evolve rapidly following establishment? Ecol Let 5:590-595

Vasquez EA, Glenn EP, Guntenspergen GR, Brown JJ, Nelson SG (2006) Salt tolerance and osmotic adjustment of Spartina alterniflora (Poaceae) and the invasive M haplotype of Phragmites australis (Poaceae) along a salinity gradient. Am J Bot 93:1784-1790
Venette R (2017) Climate analyses to assess risks from invasive forest insects: simple matching to advanced models. Curr For Rep 3:255-268

Wilson JK, Ruiz L, Davidowitz G (2019) Dietary protein and carbohydrates affect immune function and performance in a specialist herbivore insect (Manduca sexta). Physiol Biochem Zool 92:58-70

Publisher's Note Springer Nature remains neutral with regard to jurisdictional claims in published maps and institutional affiliations. 